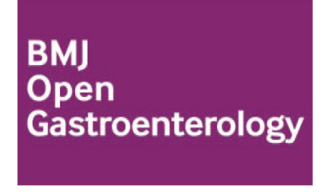

\section{The value of anal swab RT-PCR for COVID-19 diagnosis in adult Indonesian patients}

To cite: Abdullah M, Sudrajat DG, Muzellina VN, et al. The value of anal swab RT-PCR for COVID-19 diagnosis in adult Indonesian patients. BMJ Open Gastro 2021;8:e000590. doi:10.1136/ bmjgast-2020-000590

Received 26 December 2020 Revised 25 March 2021 Accepted 27 March 2021

Check for updates

(C) Author(s) (or their employer(s)) 2021. Re-use permitted under CC BY-NC. No commercial re-use. See rights and permissions. Published by BMJ.

For numbered affiliations see end of article.

Correspondence to Dr Virly Nanda Muzellina; dr_virlynanda@yahoo.com

\section{ABSTRACT}

Objective This study will test the performance of the anal swab PCR test when compared with the nasopharyngeal swab PCR test as a diagnostic tool for COVID-19.

Design An observational descriptive study which included hospitalised suspected, or probable cases of hopitalised COVID-19 patients, conducted in Dr. Cipto Mangunkusumo National Hospital, Ciputra Hospital, Mitra Keluarga Depok Hospital and Mitra Keluarga Kelapa Gading Hospital, Indonesia. Epidemiological, clinical, laboratory and radiology data were obtained. Nasopharyngeal and anal swabs specimens were collected for SARS-CoV-2 RNA detection.

Results We analysed 136 subjects as part of this study. The clinical spectrum of COVID-19 manifesation in this study was typical of hospitalised patients, with $25 \%$ classified as mild cases, $14.7 \%$ in severe condition and $12.5 \%$ of subjects classified as having acute respiratory distress syndrome. When compared with nasopharyngeal swab as the standard specimen for reverse transcription polymerase chain reaction (RT-PCR) detection of SARSCoV-2 antigen, the sensitivity and specificity of the anal swab was $36.7 \%$ and $93.8 \%$, respectively. The positive and negative predictive value were $97.8 \%$ and 16.5 $\%$, respectively. The performance of the anal swab remained similar when only the subgroup of patients with gastrointestinal symptoms $(n=92,67.6 \%)$ was analysed (sensitivity $40 \%$ and specificity $91.7 \%$ ). Out of all the subjects included in analysis, $67.6 \%$ had gastrointestinal symptoms. Similarly, $73.3 \%$ of patients in the anal swabpositive group had gastrointestinal symptoms. The two most common gastrointestinal symptoms in the subjects' population were nausea and anorexia.

Conclusion Anal swab specimen has low sensitivity $(36.7 \%)$ but high specificity (93.8\%) for detecting SARSCoV-2 antigen by RT-PCR. Only one additional positive result was found by anal swab among the nasopharyngeal swab-negative group. Anal swab may not be needed as an additional test at the beginning of a patient's diagnostic investigation and nasopharyngeal swab RT-PCR remains as the standard diagnostic test for COVID-19.

\section{INTRODUCTION}

Since the authorities in Wuhan, China, announced a cluster of pneumonia cases on

\section{Summary box}

What is already known about this subject?

- Positive RT-PCR results of SARS-COV-2 RNA were found not only in the respiratory tract but also in other specimens including faeces and biopsy specimens from the stomach, duodenum, ileum and rectum.

What are the new findings?

- This study found that anal swab RT-PCR have low sensitivity (36.7\%) compared with nasopharyngeal swab as the standard specimen. Specificity is $93.8 \%$. Similar sensitivity and specificity was found when only the subgroup of subjects who had gastrointestinal symptoms are analysed (40\% and $97 \%$, respectively).

How might it impact on clinical practice in the foreseeable future?

- Anal swab may not be needed as an additional test at the beginning of a patient's diagnostic investigation. Only one additional positive case was found using anal swab when nasopharyngeal swab was negative for SARS-CoV-2.

31 December 2019, to date (January 2021), the SARS COV-2 virus has infected more than 100 million people with a mortality rate of $2.2 \%{ }^{1}$

In Indonesia, there were more than one million confirmed cases with $2.8 \%$ mortality rate. Until January 2021, 25\% of the confirmed case in Indonesia came from the country's capital, Jakarta. $^{2}$

Gastrointestinal (GI) symptoms are a common feature in COVID-19 patients presenting to hospital. In Indonesia alone, data from the COVID-19 Handling Task Force showed nausea $(17.9 \%)$, abdominal pain $(7.4 \%)$, and diarrhoea $(7.2 \%)$, were found in patients with confirmed COVID-19. ${ }^{3}$ Meanwhile, positive RT-PCR results were found not only in the respiratory tract but also in GI 
tract specimens including faeces $(29 \%-53.42 \%$ positivity rate), ${ }^{45}$ anal swabs ${ }^{6}$ and endoscopic biopsy specimens from stomach, duodenum, ileum and rectum. ${ }^{7}$ Stool viral RNA was detected in $38.5 \%$ of those with diarrhoea, and $8.7 \%$ in the non-diarrhoea group, ${ }^{8}$ meaning that even in the absence of diarrhoea, faecal specimen RT-PCR may still be diagnostic for COVID-19. One study reports $55 \%$ of patients with positive faecal SARS-CoV-2 RNA had a prolonged positive result (mean 11.2 days) after the respiratory specimens became negative. The authors suggest that fecal-oral transmission is possible even after respiratory specimens become negative. ${ }^{9}$

There are also reports of positive SARS-CoV-2 RT-PCR of anal swab specimens in the absence of positive nasopharyngeal swab results. ${ }^{10} 11$ These findings certainly need further investigation because it raises the possibility of COVID-19 cases undetected by nasopharyngeal swab but detected by anal swab. An anal swab specimen is expected to be an alternative to specimens from the nasopharynx for SARS-CoV-2 RT-PCR.

\section{AIM}

This study will test the performance of the anal PCR swab test when compared with the nasopharyngeal swab PCR test as a diagnostic tool for COVID-19.

\section{METHODS}

\section{Study design}

This study is an observational descriptive study by detection of viral particles by RT-PCR on anal swabs from patients with suspected or probable COVID-19 infection. To estimate the sample size for this diagnostic study, an estimated prevalence of $52.6 \%$ positive anal swab specimen ${ }^{6}$ were used. The minimum requirement is to include 66 subjects. Consecutive sampling were conducted and patients meeting the inclusion criteria were recruited to the study on consent.

\section{Participants}

This study was conducted in Dr. Cipto Mangunkusumo National Hospital, Ciputra Hospital Citra Garden City, Mitra Keluarga Depok Hospital and Mitra Keluarga Kelapa Gading Hospital, Indonesia, between July 2020 and November 2020. Informed consent was obtained from each subject. The inclusion criteria were in-hospital suspected or probable COVID-19 patients based on Indonesia's National COVID-19 Prevention and Control Guidelines, ${ }^{12}$ who had undergone nasopharyngeal swab to obtain specimen for the detection of viral particles by RT-PCR. The exclusion criteria were profuse diarrhoea, massive haematochezia or melena and anal wound.

\section{Indonesia's national COVID-19 criteria}

The operational definition of COVID-19 case in Indonesia uses several terminology: suspected, probable and confirmed cases.
A patient falls into the category of suspected case when (1) acute respiratory infection is present with history of travelling or living in area with local transmission within the past 14 days, (2) acute respiratory infection is present with COVID-19 contact within the past 14 days and (3) severe pneumonia/acute respiratory infection that requires hospitalisation without any other possible aetiology other than COVID-19.

A patient is classified as a probable case when severe acute respiratory infection/acute respiratory distress syndrome (ARDS)/death occurs, with high clinical probability of COVID-19 but the RT-PCR results is not yet confirmed, while confirmed cases are people with confirmed SARS-CoV-2 infection by RT-PCR. ${ }^{12}$

\section{Specimen collection and processing}

Nasopharyngeal swab was done by entering the swab straight along the floor of the nose until resistance was met, indicating that the swab had reached the posterior nasopharynx. The swab was then rotated several times and withdrawed. Anal swab specimen was collected by inserting the swab into the anus with a length of $3-5 \mathrm{~cm}$ from the end of the swab, followed by turning the stick $360^{\circ}$ and leaving it for about $20 \mathrm{~s}$. In order to make it easier for the swab stick to enter the anus, the wand can be dipped in saline solution first.

After collection, swab sticks were inserted into viral transport medium tube. Each specimens were extracted using Total RNA Extation Miniprep extraction kit from Viogene. Extraction was performed based on manufacturer's protocol. PCR amplification used kit from MiRXES Fortitude V.2.1 Singapore, and machine used was Roche Light Cycler 480 (Roche, Basel Switzerland). Cut-off cycle threshold (CT) value of the kit was 40 , which means if CT value below 40 and amplification curve was present, the sample was valued as positive, and if otherwise, negative.

Participants were asked about GI and non-GI symptoms using a standardised case report form approved by the Ethics Committee of the Faculty of Medicine, Universitas Indonesia, and data were recorded using Microsoft Excel.

\section{Statistical analysis}

Data were expressed as counts and percentages for categorical variables and as mean and $\mathrm{SD}$ or median and $\mathrm{IQR}$ for continuous variables. The sensitivity, specificity, positive predictive value and negative predictive value were then counted. All analyses were performed with SPSS software, V.26.0 (IBM).

\section{RESULTS}

We analysed 136 subjects in this study. Sixty-six (48.5\%) are male, and $70(51.5 \%)$ are female. The mean age of the participants was 44.4 years old. Majority (52.5\%) are between 40 and 60 years old. Most of these patients reported one or more comorbidities: type 2 diabetes mellitus $(n=20)$, hypertension $(n=20)$, pulmonary diseases $(n=1)$, heart diseases $(n=7)$, malignancies $(n=4)$ 
Table 1 Demographics and baseline characteristics of COVID-19 patients according to SARS-CoV-2 RNA detection in anal swab

\begin{tabular}{|c|c|c|c|}
\hline Characteristics & $\begin{array}{l}\text { All Patients } \\
(136) \text { n (\%) }\end{array}$ & $\begin{array}{l}\text { Patients with positive } \\
\text { nasopharyngeal swab } \\
\text { SARS-CoV-2 (120) n (\%) }\end{array}$ & $\begin{array}{l}\text { Patients with positive } \\
\text { anal } \\
\text { swab SARS-CoV-2 (45) } \\
\text { n (\%) }\end{array}$ \\
\hline Age, year $(\operatorname{mean} \pm S D)$ & $44.41 \pm 12.72$ & $44.17 \pm(12.35)$ & $45.31 \pm(13.26)$ \\
\hline$<40$ n (\%) & $48(35.3)$ & 47 (39.2) & $16(35.6)$ \\
\hline $40-60$ n (\%) & 71 (52.2) & $56(46.7)$ & $24(53.3)$ \\
\hline$>60 \mathrm{n}(\%)$ & $17(12.5)$ & 17 (14.2) & $5(11.1)$ \\
\hline \multicolumn{4}{|l|}{ Sex } \\
\hline Male, n (\%) & $66(48.5)$ & $59(49.2)$ & $24(53.3)$ \\
\hline Female, n (\%) & $70(51.5)$ & $61(50.8)$ & $21(46.7)$ \\
\hline \multicolumn{4}{|l|}{ Comorbidity } \\
\hline No comorbid & $53(39)$ & $48(40)$ & $22(48.9)$ \\
\hline$<2$ & $63(46.3)$ & $57(47.5)$ & $18(40)$ \\
\hline$\geq 2$ & $20(14.7)$ & $15(12.5)$ & $5(11.1)$ \\
\hline \multicolumn{4}{|l|}{ Habits } \\
\hline Exercise, $\mathrm{n}(\%)$ almost never & $64(47.1)$ & $52(43.3)$ & $23(51.1)$ \\
\hline $\begin{array}{l}\text { Lack of exercise }(<3 x / \text { week },<30 \mathrm{~min} / \\
\text { session) }\end{array}$ & $72(52.9)$ & $68(56.7)$ & $22(48.9)$ \\
\hline \multicolumn{4}{|l|}{ Smoking, n (\%) } \\
\hline Never & $115(84.6)$ & $101(84.2)$ & $38(84.4)$ \\
\hline Active smokers & $15(11)$ & $14(11.7)$ & $4(8.9)$ \\
\hline Former smokers & $6(4.4)$ & $5(4.2)$ & $3(6.7)$ \\
\hline \multicolumn{4}{|l|}{ Body mass index } \\
\hline$<18.5$ & $5(3.7)$ & $3(2.5)$ & $0(0)$ \\
\hline $18.5-24.9$ & $69(50.7)$ & $61(50.8)$ & $30(66.7)$ \\
\hline$\geq 25$ & $62(45.6)$ & $56(46.7)$ & 15 (33.3) \\
\hline \multicolumn{4}{|l|}{ Radiologic findings } \\
\hline Pneumonia, n(\%) & $100(73.5)$ & $90(75)$ & $38(84.4)$ \\
\hline \multicolumn{4}{|l|}{ Clinical outcome } \\
\hline ARDS, n (\%) & $17(12.5)$ & $14(11.7)$ & 7 (15.6) \\
\hline ICU referral, n (\%) & $20(14.7)$ & $18(15)$ & $8(17.8)$ \\
\hline HFNO, n (\%) & $14(10.3)$ & $12(10)$ & $4(8.9)$ \\
\hline
\end{tabular}

ARDS, acute respiratory distress syndrome; HFNO, high-flow nasal oxygen; ICU, intensive care unit.

and obesity (according to Asia-Pacific classification: body mass index $>25 \mathrm{~kg} / \mathrm{m}^{2}, \mathrm{n}=62$ ). Characteristics of the subjects are described in table 1 .

Out of all the subjects included in analysis, $67.6 \%$ had GI symptoms. Similarly, $73.3 \%$ of patients in the anal swab-positive group had GI symptoms. The frequencies of GI symptoms reported by our patients are presented in table 2 .

Table 3 shows that 44 out of all patients confirmed positive with nasopharyngeal swab were also found positive with anal swab. When compared with nasopharyngeal swab as the standard specimen for RT-PCR detection of SARS-CoV-2 antigen, the sensitivity and specificity of the anal swab was $36.7 \%$ (95\% CI $28 \%$ to $45.3 \%$ ) and $93.8 \%$
(95\% CI $81.9 \%$ to $100 \%$ ), respectively. The positive and negative predictive value were $97.8 \%$ (95\% CI $93.5 \%$ to $100 \%$ ) and $16.48 \%(8.9 \%$ to $24.1 \%)$, respectively. The performance of the anal swab remained similar when only the subgroup of patients with GI symptoms $(n=92$, $67.6 \%$ ) was analysed (sensitivity $40 \%$ (95\% CI $29.2 \%$ to $50.7 \%$ ) and specificity $91.7 \%$ (95\% CI $91.1 \%$ to $100 \%)$.

The clinical spectrum of COVID-19 manifesation in this study was typical of hospitalised patients, with $25 \%$ classified as mild cases according to national guidelines (had non-specific symptoms such as fever, cough, sore throat, stuffed nose, malaise, headache and muscle aches), $14.7 \%$ in severe condition (one or more criteria are met: respiratory rate $>30 / \mathrm{min}$, presence of respiratory distress 


\begin{tabular}{|c|c|c|c|}
\hline & $\begin{array}{l}\text { All Patients } \\
\text { (136) n (\%) }\end{array}$ & $\begin{array}{l}\text { Patients with positive } \\
\text { nasopharyngeal swab } \\
\text { SARS-CoV-2 (120) n (\%) }\end{array}$ & $\begin{array}{l}\text { Patients with } \\
\text { positive anal } \\
\text { swab SARS- } \\
\text { CoV-2 (45) n (\%) }\end{array}$ \\
\hline Gastrointestinal symptoms, n (\%) & $92(67.6)$ & $81(67.5)$ & $33(73.3)$ \\
\hline Anorexia & $63(46.3)$ & $56(46.7)$ & $24(53.3)$ \\
\hline Bloated stomach & $26(19.1)$ & $24(20)$ & $11(24.4)$ \\
\hline Diarrhoea & $17(12.5)$ & $15(12.5)$ & $8(17.8)$ \\
\hline Constipation & $4(2.9)$ & $3(2.5)$ & $0(0)$ \\
\hline Nausea & $64(47)$ & $58(48.3)$ & $25(55.6)$ \\
\hline Vomiting & $21(15.4)$ & $19(15.8)$ & $8(17.8)$ \\
\hline Abdominal pain & $28(20.6)$ & $25(20.8)$ & $9(20)$ \\
\hline
\end{tabular}

or oxygen saturation $<90 \%$ at room air) and $12.5 \%$ of subjects classified as having ARDS according of the fifth version of Indonesia's National COVID-19 Prevention and Control Guidelines.

\section{DISCUSSION}

RT-PCR from nasopharyngeal specimen is still the gold standard for the diagnosis of SARS CoV-2. However, the sensitivity varies, depending on the timing of the test relative to exposure. ${ }^{13} 1415$ Our study found 45 (37.8\%) anal swab-positive patients out of 136 subjects. Fifteen $(11.03 \%)$ of the patients that were suspected to have COVID-19 clinically were found to be negative both by nasopharyngeal and anal swab RT-PCR.

There is not much research that provides data on RT-PCR anal swabs for the diagnosis of COVID-19. More reports, however, were found on faecal RT-PCR. Yuan et al found $52.6 \%$ positive results on anal swab examination in children. ${ }^{16}$ Another study reports anal swab positivity rate of $24.32 \%$, and found two subjects with positive anal swab but negative nasopharyngeal swab. ${ }^{17}$ This is similar to our finding, where one patient had positive anal swab result with negative nasopharyngeal swab RT-PCR. This particular patient had two negative nasopharyngeal swab 2 days apart, both negative, but CT scan showed multifocal ground glass opacities and the patient is considered a COVID-19 probable case. These findings suggests that anal swab may find additional COVID-19 case when respiratory specimens are negative. A study by Wang et al reports that anal swab had higher positivity rate $(20 \%)$ than pharyngeal swab (12\%) in detecting SARS-CoV-2 nucleid acid among convalescent COVID-19 patients. In

Table 3 Correlation of nasopharyngeal swab and anal swab of the study population

\begin{tabular}{llll} 
& $\begin{array}{l}\text { Positive } \\
\text { nasopharyngeal } \\
\text { swab (n) }\end{array}$ & $\begin{array}{l}\text { Negative } \\
\text { nasopharyngeal } \\
\text { swab (n) }\end{array}$ & \\
\hline $\begin{array}{l}\text { Positive anal swab } \\
\text { (n) }\end{array}$ & 44 & 1 & 45 \\
$\begin{array}{l}\text { Negative anal swab } \\
\text { anal (n) }\end{array}$ & 76 & 15 & 91 \\
\hline
\end{tabular}

10 patients with positive anal swab, nine cases had negative respiratory tract specimens. ${ }^{18}$

The sensitivity of the anal swab in this study is indeed low, so it is not ideal if it is used as a diagnostic tool for COVID-19 screening. However, with a specificity of $93.8 \%$, it can be said that it is good enough for a confirmation test for COVID-19. We also found that anal swab's sensitivity and specificity remain similar regardless of the presence of GI symptoms.

In this study, we found that $67.6 \%(n=92)$ of the subjects complained of GI symptoms. The most common GI symptoms in the subject's population is nausea $(47 \%)$, followed by anorexia $(46.3 \%)$.

Pan et al reported $50 \%$ of patients present with digestive symptoms, and a small proportion of patients $(3 \%)$ presented solely with GI symptoms ${ }^{19}$ GI involvement is also often found in infections of related viruses from the Coronaviridae family, namely SARS-CoV and MERS-CoV. During the SARS outbreak, more than $76 \%$ of patients had diarrhoea, generally in the first 1 week of illness. Intestinal biopsy shows active replication of SARS-CoV in both small and large intestine. ${ }^{20}$ It is known that SARS-CoV-2 binds to ACE-2 as its main receptor for cell entry. The tissues of GI tract express high level of ACE-2 on cell surfaces and data suggests that the small intestine express the highest level of ACE-2 among all tissues in human body. ${ }^{21}$ This high expression of ACE-2 is a potential site of SARS-CoV-2 binding, and potentially contributes to subsequent GI tract infection and digestive symptoms.

During the study, there were no complications or complaints from patients about the anal swab procedure.

\section{CONCLUSION}

RT-PCR anal swabs is a good confirmatory test for COVID-19 cases (specificity 93.8\%). However, this study found only one additional COVID-19 case by anal swab when respiratory specimens were negative, which may imply that RT-PCR from respiratory specimens should still be used as a primary diagnostic test, and anal swab may not be needed as additional test at the beginning of a patient's investigation. We consider anal swab as a safe procedure for patients, but although there were no complaints from patients during or after the 
procedure, the comfort and acceptability aspects of anal swab were not included in this study and further research may be needed.

\section{Author affiliations}

${ }^{1}$ Gastroenterology, Pancreatobilliary, and Endoscopy Division, Internal Medicine Department, Rumah Sakit Umum Pusat Nasional Dr Cipto Mangunkusumo, Central Jakarta, Special Capital Region of Jakarta, Indonesia

${ }^{2}$ Indonesia Medical Education and Research Institute - Human Cancer Research Center, University of Indonesia Faculty of Medicine, Central Jakarta, Special Capital Region of Jakarta, Indonesia

${ }^{3}$ Hepatobilliary Division, Internal Medicine Department, Rumah Sakit Umum Pusat Nasional Dr Cipto Mangunkusumo, Central Jakarta, Special Capital Region of Jakarta, Indonesia

${ }^{4}$ Geriatric Division, Internal Medicine Department, Rumah Sakit Umum Pusat Nasional Dr Cipto Mangunkusumo, Central Jakarta, Special Capital Region of Jakarta, Indonesia

${ }^{5}$ Department of Clinical Pathology, Rumah Sakit Umum Pusat Nasional Dr Cipto Mangunkusumo, Central Jakarta, Special Capital Region Jakarta, Indonesia ${ }^{6}$ Research Center for Virology and Cancer Pathobiology, University of Indonesia Faculty of Medicine, Jakarta, Special Capital Region of Jakarta, Indonesia ${ }^{7}$ Psychosomatic and Palliative Care Division, Internal Medicine Department, Faculty of Medicine, Universitas Indonesia, Cipto Mangunkusumo Hospital, Rumah Sakit Umum Pusat Nasional Dr Cipto Mangunkusumo, Central Jakarta, Special Capital Region of Jakarta, Indonesia

${ }^{8}$ Hematology and Medical Oncology Division, Internal Medicine Department, Faculty of Medicine, Universitas Indonesia, Cipto Mangunkusumo Hospital, Rumah Sakit Umum Pusat Nasional Dr Cipto Mangunkusumo, Central Jakarta, Special Capital Region of Jakarta, Indonesia

${ }^{9}$ Respirology and Critical Care Division, Internal Medicine Department, Faculty of Medicine, Universitas Indonesia, Cipto Mangunkusumo Hospital, Rumah Sakit Umum Pusat Nasional Dr Cipto Mangunkusumo, Central Jakarta, Special Capital Region of Jakarta, Indonesia

Acknowledgements This research/article's publication is supported by Indonesian Ministry of Research, Technology and Higher Education through the Penelitian Terapan Unggulan Perguruan Tinggi (PTUPT) Program Contract NKB-288/ UN2.RST/HKP.05.00/2020. We express our gratitude to this research especially to Virology and Cancer Pathology Research Center, Faculty of Medicine, Universitas Indonesia for allowing the use of PCR amplification used kit from MiRXES Fortitude 2.1 Singapore, and Roche Light Cycler 480 Machine, Ajeng Apsari Utami and Frisky Ronald Tua as research assistants of Division of Gastroenterology, Department of Internal Medicine, Faculty of Medicine, Universitas Indonesia, Cipto Mangunkusumo Hospital, Jakarta, Indonesia. The grant support is independent of the investigation process and write-up.

Contributors Concept: MA; Design: MA and APU. Supervision: MA and APU; Resources: MA and APU; Materials: MA, APU and SM; Data Collection and/or Processing: MFI, AS, VNM, DGS, YY and SM; analysis and/or Interpretation: MA, APU and VNM; Literature Search: RRP, AS, VNM, DGS, JK and AR; writing Manuscript: MA, APU, VNM; critical review: MA, APU, HS, IR, CWP, KR.

Funding This research/article's publication is supported by Indonesian Ministry of Research, Technology, and Higher Education through the Penelitian Terapan Unggulan Perguruan Tinggi (PTUPT) Program Contract NKB-288/UN2.RST/ HKP.05.00/2020.

Competing interests MA reports grants from Indonesian Ministry of Research, Technology and Higher Education during the conduct of the study. DGS has nothing to disclose. VNM has nothing to disclose. JK has nothing to disclose. AR has nothing to disclose. APU has nothing to disclose. RRP has nothing to disclose. MFI has nothing to disclose. YY has nothing to disclose. SM has nothing to disclose. AS has nothing to disclose. HS has nothing to disclose. IR has nothing to disclose. CWP has nothing to disclose. KR has nothing to disclose.

Patient consent for publication Not required.

Ethics approval The study was approved by the Ethics Committee of the Faculty of Medicine, Universitas Indonesia on 22 June 2020 with the approval number KET-639/UN2.F1/ETIK/PPM.00.02/2020.

Provenance and peer review Not commissioned; externally peer reviewed.
Data availability statement All data relevant to the study are included in the article or uploaded as online supplemental information. The authors confirm that the data supporting the findings of this study are available within the article and its online supplemental materials.

Open access This is an open access article distributed in accordance with the Creative Commons Attribution Non Commercial (CC BY-NC 4.0) license, which permits others to distribute, remix, adapt, build upon this work non-commercially, and license their derivative works on different terms, provided the original work is properly cited, appropriate credit is given, any changes made indicated, and the use is non-commercial. See: http://creativecommons.org/licenses/by-nc/4.0/.

ORCID iD

Murdani Abdullah http://orcid.org/0000-0002-8801-0283

\section{REFERENCES}

1 Coronavirus Update (Live): 101,433,090 Cases and 2,184,120 Deaths from COVID-19 Virus Pandemic - Worldometer [Internet]. Worldometers.info, 2020. Available: https://www.worldometers.info/ coronavirus/ [Accessed 28 Jan 2020]

2 BNPB. [Internet]. Covid19.go.id. 2021. Available: https://covid19.go. id/peta-sebaran [Internet] [Accessed 28 Jan 2020].

3 COVID-19 S. Peta Sebaran | Satgas Penanganan COVID-19 [Internet]. covid19.go.id, 2020. Available: https://covid19.go.id/petasebaran [Accessed cited 4 November 2020].

4 Wang W, Xu Y, Gao R, et al. Detection of SARS-CoV-2 in different types of clinical specimens. JAMA 2020;2.

5 Xiao F, Tang M, Zheng X, et al. Evidence for gastrointestinal infection of SARS-CoV-2. Gastroenterology 2020;158:1831-3.

6 Yuan $\mathrm{C}$, Zhu H, Yang Y, et al. Viral loads in throat and anal swabs in children infected with SARS-CoV-2. Emerg Microbes Infect 2020;9:1233-7.

7 Martínez H I, Pérez L, Moya M. Presence of SARS-Coronavirus-2 in the ileal mucosa: another evidence for infection of Gi tract by this virus. Gastroenterology 2020.

8 Lin L, Jiang X, Zhang Z, et al. Gastrointestinal symptoms of 95 cases with SARS-CoV-2 infection. Gut 2020:69:997-1001.

9 Wu Y, Guo C, Tang L, et al. Prolonged presence of SARS-CoV-2 viral RNA in faecal samples. Lancet Gastroenterol Hepatol 2020;5:434-5.

10 Jiang X, Luo M, Zou Z, et al. Asymptomatic SARS-CoV-2 infected case with viral detection positive in stool but negative in nasopharyngeal samples lasts for 42 days. $J$ Med Virol 2020;92:1807-9.

11 Xu C, Song J, Liu S, et al. [Analysis of the positive rate of anal swab nucleic acid test and clinical characteristics in patients with different severity of coronavirus disease 2019]. Zhonghua Wei Zhong Bing Ji Jiu Yi Xue 2020;32:1171-3.

12 Kementerian Kesehatan RI. Pedoman Pencegahan DAN Pengendalian coronavirus disease (COVID-19. Jakarta: Kemenkes $\mathrm{RI}, 2020$.

13 Perhimpunan Dokter Spesialis Mikroiologi Klinik. Panduan Pemeriksaan Mikrobiologi Klinik untuk Penegakan diagnosis Covid-19. Jakarta: PAMKI, 2020.

14 Kucirka LM, Lauer SA, Laeyendecker O, et al. Variation in falsenegative rate of reverse transcriptase polymerase chain reactionbased SARS-CoV-2 tests by time since exposure. Ann Intern Med 2020;173:262-7.

15 Wang W, Xu Y, Gao R, et al. Detection of SARS-CoV-2 in Different types of clinical specimens. JAMA 2020;2.

16 Yuan C, Zhu H, Yang Y, et al. Viral loads in throat and anal swabs in children infected with SARS-CoV-2. Emerg Microbes Infect 2020;9:1233-7.

17 Li L, Tan C, Zeng J, et al. Analysis of viral load in different specimen types and serum antibody levels of COVID-19 patients. J Transl Med 2021;19:30.

18 Wang X, Zhu Y, Li T, et al. Evaluation of SARS-COV-2 nucleic acid in convalescent anal swabs of patients with coronavirus disease 2019. Tianjin Medical Journal 2020;48:592-5.

19 Pan L, Mu M, Yang P, et al. Clinical characteristics of COVID-19 patients with digestive symptoms in Hubei, China: a descriptive, cross-sectional, multicenter study. Am J Gastroenterol 2020;115:766-73.

20 Ding S, Liang TJ. Is SARS-CoV-2 also an enteric pathogen with potential Fecal-Oral transmission? A COVID-19 virological and clinical review. Gastroenterology 2020;159:53-61.

21 Zhang H, Li H-B, Lyu J-R, et al. Specific ACE2 expression in small intestinal enterocytes may cause gastrointestinal symptoms and injury after 2019-nCoV infection. Int J Infect Dis 2020;96:19-24. 